\title{
Lady Lazarus Revisited: Reflections of a psychiatrist on the poetry and illness of Sylvia Plath
}

\author{
Laszlo Varga, M.D., Ph.D.*
}

Psychiatric physicians have always been attracted to study art and mental illness and Sylvia Plath's tragic history is an outstanding example for such an inquiry.

The current paper received inspiration by the news that a movie has been recently completed about Sylvia Plath, and released. Therefore it was felt that some renewed reflections about her poetry and mental illness would be a timely effort. This paper is not a biography, nor any attempt for a concise analysis. Only a few selected impressions are offered here for the interested reader with some comments about "Fate" and "Determinism" in Plath's poetry. She suffered a very serious psychotic break necessitating prolonged hospitalization, but her formal diagnosis was never revealed to the public. We know that she received 26 electroconvulsive treatments which calls attention toward schizophrenia. But her general behavior as it appears in her biographies does not reveal this illness, though in her daily life she had many small bizarre elements. Schizoid personality would be one acceptable suggestion. The difficulty is buried in our recent diagnostic classification which significantly differ from that in 1963 at the time of Plath's suicide. Bipolar Disorder with a severe psychotic break would be another possibility according to our recent nomenclature, but we wish to avaoid actual compartmentalization.

Glory and fame was not attained in her lifetime. This elevated literary status arrived to her through the bitterest human deed: a reproachful abandonment of

*To whom correspondence should be addressed:Dr. Laszlo Varga, 208 Woodlawn Rd, Keene, Texas 76059 herself to death. Shocking as it may be, her suicide served as a glorification of her poetic career, creating a certain literary fame that survives. Readers, young and even mature poets, grouped around her memorial legacy, paid astounded tribute to her, elevating Plath to a kind of priestess of contemporary poetry. Ann Sexton, Marianne Moore, and no less a literary leader than Richard Wilbur paid homage to her poetic achievements. George Steiner (1) went so far as to call her most demonic poem, Daddy, the Guernica of modern poetry. Certainly, not all these idolatrous responses are appropriate, but there can be no doubt that they signify the acceptance of Plath's new style and manner of lyric writing: her air of peremptory competence. In this air, created by her, reproach, disappointment and suicide are the dominating elements in her poetry.

Looking at the treatments of mental illness, we often see the fact that the physician is at a disadvantage to help, because the patient is not the ally, but frequently the enemy of psychiatric intervention. The poems of Sylvia Plath serve as a penetrating literary example of the mental imagery of the psychotic artist, who has opened the Pandora's Box of her inner mental world.

\author{
So, so, Herr Doktor for \\ So, Herr Enemy \\ I am your opus, \\ I am your valuable, \\ The pure gold baby
}

That melts to a shriek.

I turn and burn. 
Do not think that I underestimate your great concern.

\author{
Ash, ash- \\ You poke and stir. \\ Flesh, bone, there is nothing there-
}

A cake of soap,

A wedding ring,

A gold filling.

Herr God, Herr Lucifer, Beware

Beware.

(Lady Lazarus)

It is not as if other creative artists haven't suffered in the stifling grip of psychiatric illness, but only Plath has been capable of conjuring the demonic representation of her mental imagery with such a high level of artistic richness. One shudders or rebels at such an outpouring of hallucinatory fervor, which shows agonizing intelligence at the border of the unconscious, often with bone-chilling preparation for suicide and death. At least the editors of the 1960's felt so, as one after the other rejected Plath's manuscripts, with comments that the intensity of her emotions over-powered form, that her verses were "out of control", and that she was "mining a destructive art" (3). These and similar comments reached her from publishers during the last few months of her life, during which she was actually forging her richest works.

The memory of her father is an ever returning image in her poetry. His loss is an incurable wound throughout her life. Her father figure is a central theme in Plath's poetry.

A garden of mouthings. Purple, scarlet-speckled,black The great corollas dilate, peeling back their silks.

Their musk encroaches, circle after circle,

A well of scents almost too dense to breathe in.

Hieratical in your frock coat, maestro of the bees, You move among the many-breasted nives,

My heart under your foot, sister of a stone.

(The Beekeeper's Daughter)

But her father, Otto Plath, an internationally known apiarist, struggled with diabetes and, as is common with many diabetics, he neglected his condition. His toes became gangrenous and one of his legs had to be amputated. Plath was eight years old when she lost her father, never fully recovering from this tragic event.
Daddy, I have had to kill you. You died before I had timeMarble-heavy, a bag full of God, Ghastly statue with one gray toe Big as a Frisco seal.

(Daddy)

The early childhood shock is probably the breeding nidus for her reproachful attitude throughout her life and for her suicidal motives. Her first experimentation with suicide, hinted at in her own poetry, dates back to her early teen years. Once she tried to slash her wrists in a hot bath, in reminiscence of the merciful death sentences of the classical Roman emperors. At another time, she slashed her face with a kitchen knife, leaving a visible scar on her left cheek. A strange indifference to pain is noted in her poetry, surmising an almost perverted pleasure form the immersion, as if her sufferings were the appurtenances of a mystic purification.

In spite of her destructive obsession, Plath completed all her schooling with honors, with the steadfast ambition and energy of the excellent student. She always wanted to be the first and the best and usually succeeded. Her first poems were published when she was only twelve years old. Later, she completed her college Summa Cum Laude. "Fame, Fame, Fame!" burned in her imagination in neon letters. Nothing was more important to her than looking at her name and poems in print. The flame of her internal cauldron lighted her to be up and typing by 4 a.m. in order to complete her most important poetic incantations before her suicide. Knowing her end was near, she wanted to leave a completed poetic inheritance. To do so, she worked with hallucinatory fervor.

During her college years, she was perceived by her teachers as a pleasant, agreeable student, charming and feminine, with youthful energy and liveliness. They did not suspect that significant consumption of alcohol, sexual debauchery, abounding egotism and selfishness were churning under the surface. In retrospect, everyone who knew Plath personally noted that there was incomprehensible and indefinable strangeness in her. Often show was observed as overly enthusiastic, with a voluble speech peppered with mysterious comments and more than once, she created an uncomfortable atmosphere about herself. Heinz Lehmann, a Canadian professor of psychiatry, writes about this uncomfortable, uneasy aura which emanates from the behavior of the schizoid person even during symptom-free times. Sylvia Plath was a master at creating such disturbing situations. Yet, she always operated with superior intelligence and baffled some of the intellectual leaders of their time. She devoured 
books and knew thoroughly about everyone important in contemporary literature, even about third-rate writers. At a tea one afternoon in Cambridge, a little known beginning poet, Lucas Meyers, asked her to dance. He listened with amazement as Plath recited his newest poem, which had been published in an obscure journal that sold only in a few dozen copies. A friendship developed between them and they corresponded for a long time.

Plath was a third year college student as Smith, when upon her arrival home from New York; she was notified that she has been rejected to take a writing class at Harvard, even though she had submitted her prize-winning short story as proof of her talent. She lost her emotional balance, tried to commit suicide again and was hospitalized. Her medical records are of confidential of course, but we do know that her condition deteriorated and she was transferred to a closed ward. She refused all contact with the outside world, and also refused to cooperate with doctors and nurses. She would not accept visitors and announced that she hated her mother. For her birthday, she received a large bouquet of yellow roses, which she immediately threw in the trash and announced "this is only for my funeral" (6). The expenses of her treatment in an exclusive hospital were covered by Mrs. Prout, a popular American novelist at that time, who established a fellowship at Smith for talented young women. Sylvia was one of the recipients of this scholarship. Still, she described her benefactor in her novel as a snobbish lesbian matron. These few examples serve only to describe the schizoid person's sense of reality.

Plath's psychiatric hospitalization lasted almost five months, in the same private sanatorium where Robert Lowell and Ann Sexton were also treated for emotional indisposition. The latter was Plath's personal friend, who also ended her life by her own hand. While in the hospital, Eric Lindemann, Chairman of Psychiatry at Harvard Medical School, supervised her therapy. Her biographers, however, were not correct in saying that Plath was humiliated or abused, because of the electroconvulsive. Nothing else helped. She would likely have remained forever in chronic care in a closed hospital ward, in a demented mental status, enticed by her hallucinatory demons if she had not received treatment.

A gray wall now, clawed and bloody.

Is there no way out of the mind?

Steps at my back spiral into a well.

There are no trees or birds in this world,

There is only a sourness.
Let us recall from medical people that about $40 \%$ of the psychotic patients do not respond to conventional anti-psychotic drugs, and Plath belonged to this group.

Plath married the English Poet Laureat Ted Hughes after a few weeks acquaintance. After lengthy travels throughout the U.S. and Europe, she and Hughes settled in England.

After seven years of marriage, in 1962, the marriage deteriorated and ended in separation. Plath's pathological and often histrionic jealousy had an important role in this; in fact, it proved to be a selffulfilling prophesy. Hughes became involved with another woman but he probably felt an ever-increasing discomfort about his wife's theatrical exaggerations, because at the time of the separation he announced that it was impossible to live with Plath.

While married, Plath idealized her husband. A marriage to Ted Hughes meant more than love and security for her: it meant a great deal of pride, status, inspiration and future. Her husband's alienation and unfaithfulness ripped open all her vulnerable, narcissistic wounds.

Where apple bloom ices the night

I walk in a ring,

A groove of old faults, deep and bitter.

Love cannot come here.

A black gap discloses itself.

On the opposite lip.

A small white soul is waving, a small white maggot.

My limbs, also, have left me.

Who has dismembered us?

The dark is melting. We touch like cripples.

(Event)

Plath did not know her own role in the cooling of her husband's emotional attachment. She did not know the burden of living daily with a semi-psychotic person, always ready to incite a degree of unease in her interpersonal environment. This is exactly what Plath was most capable of doing in her private life.

The plain clinical truth is that her inspirational driving forces stemmed from her inner wounds. In a polemic vengeance for her lost happiness she cried out with a quotation from Virgil: "Excoriar aliquis nostris ex ossibus ultor" (7).

It is almost banal but still significant to note that after her suicide the publishers coveted exactly those writings which they had rejected earlier. Suddenly, Plath became considered to be among the most notable 
authors of modern American Literature, perhaps surpassing even Emily Dickinson. However, her abandonment of the contemporary academic style created a conflagration of arguments about the significance of her poetry.

She fantasized that like the bird Phoenix rising from its ashes, she too would rise again free after suicide. She believed that afterwards she would achieve a life without inner turmoil, leaving her demons behind. In her verses, the objects of the outside world rapidly transcend to themes of hallucinatory projections, only to present astonishing, but dazzlingly bizarre images to the reader.

Out of kitchen table or chair

As if a celestial burning took

Possession of the most obtuse object -- now and then -Thus hallowing an interval

Otherwise inconsequent

By bestowing largess, honor

One might say love.

(Black Rook in a Rainy Weather)

She led a life of self-absorption, reproaching the world, which she perceived distortedly, through the glass of her novel The Bell Jar. Sylvia Plath was an unusually complicated lyrical poet in an environment which, in those days, scorned lyrical poetry. Plath remained self-occupied, brooding over the thwarting machinations of her inner demons, who were sending undefined, but dangerous commands, ominously approaching.

But is it necessary to scrutinize the mental status of a poet while analyzing her art? Is it possible to describe her poetry as clinical? The borderline is obviously indiscernible and the rest is almost impossible to answer. Naturally, it is not necessary to know the details of Sylvia Plath's life in order to appreciate her poetry. Literary work stands on its own, whether it is pure or inflamed, sublime or vulgar, or clinical. Nevertheless, analytic scrutiny always points to and searches for connections between a work and its creator's life. Nothing is more interesting to a reader than to learn the details of an author's life in connection with the finished work. This desire is not entirely wrong, for such an interpretation can enhance our appreciation of the poetic craft. The verse is not purely the product of the creator's conscious effort; it is also the product of her unconscious motives. These details are the most exciting psychological detective work. Plath was a confessional poet, as her biographers and critics called her. She knew very well that she and all such poets, are denuded before the public eye:
The peanut-crunching crowd

Shoves in to see

The big strip tease

Gentlemen, ladies,

These are my hands,

My knees.

I may be skin and bone,

Nevertheless, I am the same, identical woman.

A miracle!

That knocks me out

There is a charge

For the eyeing of my scars

For hearing of my heart

It really goes.

And there is a charge

A very large charge

For a word or a touch

Or bit of blood

(Lady Lazarus)

These lines were written after one of her suicide attempts.

During the last year of her life, her poetry rapidly matured. Her marmoreal poetic style appeared more chiseled and elegant. Her vituperative power bore to existence such poems as the initially "ill famed", but now highly reputed, Daddy and Lady Lazarus. However, her personality became less pleasant. She expressed her opinion without inhibition (and we don't have to explain how popular someone may be who always speaks the truth). Now and again, she came close to another collapse.

The incomprehensible psychic powers reclaimed her. In early 1963 she suffered from restless insomnia, which she tried to vanquish with ever-increasing sedatives. She knew too well how to hide her troubles from her friends, and when they finally noticed her state, it was too late. They knew nothing of her first hospitalization and illness. It had been kept secret from her English acquaintances.

There are unaccustomed terrains in Plath's poetry, her inspiration rarely came from ethereal domains of the Muses, but rather from the synclinal smelting furnace of the unconscious.

The covenants of creative work and psychotic illness arrived to a final common path: the inherent predestination to an end, the inevitability towards both, the ill and the artist are attracted to each other in a 
magnetic stream. There is indeed an unexplained influence in the psychotic patient within, pulling him in one and only one possible direction. He is unable to liberate himself - like the fruitless effort in sleep paralysis - from this irresistible force. There is no other way; to surrender to the psychotic delusion is an intractable necessity.

This constraint in the ill is the will in the artist. He, too, is struggling toward the inevitable, i.e. for perfection, for which he is willing to give away his life, just to make sure that one verse or line or note or brushstroke correctly follows the others. There is a drama in this effort, pessimistic not heroic, inherited from the classical Greeks with an unmerciful "necessity" in our Western literary tradition. Therefore, Plath's suicide is not viewed as an accident or disturbance in a depressive moment, losing the Self. We respectfully disagree with A. Alvarez's interpretation (11) that she did not really want to commit suicide, that her act was only a planned cry for help. Such a style of the neurotic housewives was disdainfully undignified for her. Plath behaved at a different level of mental functioning and we believe that she planned her suicide. She had no other choice. She condemned herself in her poetry and had to follow her inner laws. She was preparing for the end; this is exactly why she worked so feverishly to complete her work. From her manuscripts, we see that she refined and finished two or three poems in a day or two, during the last few months of her life. After she reaped her harvest, completed her poems in frightful rendition, she gave herself to her demons. In Plath's history, the demons were her reality. The conclusions waited for her, as though at the end of a railroad track, with no deviation.
She followed her own irreversible moral laws:

The woman is perfected.

Her dead

Body wears the smile of accomplishment, The illusion of a Greek necessity

Flows in the scrolls of her toga,

Her bare

Feet seem to be saying;

We have come so far, it is over.

(Edge)

\section{REFERENCES}

1. The Plath Celebration: A Partial Dissent, by Irvin Howe in Sylvia Plath: The Woman and the Work, by Ed. E. Butcher, Dodd Mead \& Co. New York 1977.

2. Bitter Fame, by Ann Stevenson, Houghton Mifflin, Boston 1989.

3. Introduction in Ariel Ascending, by P. Alexander, Editor by Harper \& Row, New York 1955,

4. The Interpretation of Schizophrenia, by S. Arieti, by Basic Books, New York 1955 (First Edition).

5. Bitter Fame (ibid.).

6. The Bell Jar, by Sylvia Plath (pseudonym of Victoria Lucas) by Heinemann, London , 1963.

7. Virgil: Aeneid "Let someone arise from my bones as an avenger".

8. The Journals of Sylvia Plath, by Ed. F. McCullough by Dial Press, New York 1982.

9. Ariel, Poems by Sylvia Plath by Harpers \& Row, New York 1961.

10. An Intractable Metal, by H. Wendler in Ariel Ascending (ibid.).

11. Sylvia Plath, A Memoir, by A. Avarez in Ariel Ascending (ibid.).

Dr. Varga received his M.D CM degree from McGill University. He was a professor of psychiatry at Loma Linda University Medical School in California. He is currently semi-retired, practicing neurology and psychiatry in the Veterans Adminstration Hospital in Dallas, Texas. 